\title{
Membrane stabilization as a mechanism of the anti-inflammatory activity of ethanolic root extract of Choi (Piper chaba)
}

\author{
Samina Yesmin ${ }^{1,2 \dagger}$, Arkajyoti Paul ${ }^{3,4+}$, Tarannum Naz ${ }^{1 *}$, A. B. M. Atiqur Rahmann', Sarkar Farhana Akhter ${ }^{1}$,
} Mir Imam Ibne Wahed ${ }^{1}$, Talha Bin Emran ${ }^{3,4}$ and Shafayet Ahmed Siddiqui, ${ }^{5,6^{*}}$ (D)

\begin{abstract}
Background: This experiment is conducted to evaluate the anti-inflammatory effect of Piper chaba roots.

Methods: The in-vitro anti-inflammatory activity of Piper chaba was carried out by human red blood cell (HRBC) membrane stabilization method which includes heat-induced hemolysis and hypo tonicity- induced hemolysis and also by another method of egg albumin denaturation assay.

Results: Anti-inflammatory activity study of crude ethanolic extract was performed using heat induced membrane stabilization method, hypo-tonicity induced HRBC membrane stabilization method and egg albumin denaturation method. Crude ethanolic extracts of $P$. chaba showed promising in vitro anti-inflammatory activity in a concentration dependent manner. Using acetyl salicylic acid (ASA) as standard drug and was compared with ethanolic extract to determine anti-inflammatory activity. Heat induced anti-inflammatory test revealed that crude ethanolic extract of $P$. chaba $(500 \mu \mathrm{g} / \mathrm{ml})$ and positive control ASA $(500 \mu \mathrm{g} / \mathrm{ml})$ have $52.667 \%$ and $78 \%$ respectively, hypo tonicity induced antiinflammatory test showed $35.67 \%$ and $59 \%$ inhibition of red blood cell (RBC) hemolysis. Egg albumin denaturation method also evaluated that crude ethanolic extract $(1000 \mu \mathrm{g} / \mathrm{ml})$ and ASA $(1000 \mu \mathrm{g} / \mathrm{ml})$ showed $60 \%$ and $97.12 \%$ inhibition of egg albumin denaturation.
\end{abstract}

Conclusion: The plant of $P$. chaba of the genus Piper possesses promising anti-inflammatory activities.

Keywords: P. Chaba, Anti-inflammatory, Denaturation, Hypo- tonicity induced hemolysis, Heat induced hemolysis

\section{Introduction}

The use of natural products having therapeutic activities is an ancient practice for human civilization and plants, minerals and animal products (Epibatidine, African clawed frog) were the primary sources of drugs since ancient time [1]. Throughout the development of human culture using of natural products has had magical-religious significanceoften been the only means to treat physical injuries and other diseases. During the last few decades in drug

\footnotetext{
* Correspondence: taranazbd@gmail.com; shafayetahmed91.sa@gmail.com ${ }^{\dagger}$ Samina Yesmin and Arkajyoti Paul contributed equally to this work.

'Department of Pharmacy, University of Rajshahi, Rajshahi 6205, Bangladesh ${ }^{5}$ Department of Pharmacy, Noakhali Science and Technology University, Noakhali 3814, Bangladesh

Full list of author information is available at the end of the article
}

discovery and drug development a secondary role was played by natural products [2].

Interest in using complementary medicine to alleviate and improve health conditions is increasing in developed countries [3]. Investigation of novel different medicinal plants from different regions of the world and their botanical utilization has increased all over the world including western world. We have a mechanistic information deficiency and a lack of possible differences amongst species from the same genus of a plant [4].

Due to harmful stimuli as pathogens, irritants and damaged cells, produce a vascular tissue response which we call inflammation [5]. Inflammation and oxidation are closely related: free radicals that damage cells lead to inflammation [6]. Inflammation, which is a preventive 
effort by organism for removing injurious stimuli alongside inflammation start a signal for healing process. The term anti-inflammatory refers to the attribute of a chemical substance alongside a treatment that can reduce inflammation. About half of analgesics are antiinflammatory drugs, relieving pain by reducing inflammation as opposed to the mechanism of opioids, which affect our central nervous system (CNS) [7]. Using overthe-counter (OTC) with non-steroidal prescription medicaments are frequently commended in case of distinctive neurosurgical practice. It is very important processing both analgesic along with anti-inflammatory activities which decidedly can bring upon several novel prospects for inflammation related diseases. Natural compounds that are rectified of plants may suffice as very good templet for discovery and design of novel anti-inflammatory lead molecules and drugs with less toxicological status because gastrointestinal problems or liver cirrhosis associated with the use of synthetic antiinflammatory drugs enduring dilemma of medical world [8]. The most substantial fallout profiles of NSAIDs and steroidal drugs is, an escalating concern for natural compounds among peoples, for instance herbal therapeutics and dietetic supplementations are expended for many centuries to scaled down inflammation and painful sensation [9]. There are confluence of naturally occurring bioactive compounds that too provide action in a similar mechanism as NSAIDs, which insert action by suppressing our inflammatory pathways. Furthermore, there are plies of naturally obtained chemical compounds that suppress nuclear factor- $\mathrm{k} \beta$ mediated inflammation pathways along with COX-pathway in our body. Reported anti-inflammatory herbal drugs with less toxicity areZingiber officinale reduces subjective pain [10]. Antiinflammatory activity has been observed in many other plants including Piper genus. Cloves, Rosemary, Turmeric has powerful anti-inflammatory punch [11]. Piper betle leaves extract (methanolic extract) has antiinflammatory activity using carrageenan-induced hind paw edema model [12]. Piperine compound is isolated from Piper nigrum can cause acute changes in inflammatory processes. Another plant from Piper genus Piper porphyrophyllum (Piperaceae) a compound- 4',5-dihydroxy-3',7-dimethoxyflavone gave anti-inflammatory activity $[13,14]$.

P. chaba (Piperaceae) a glabrous climbing shrub popularly known as 'Choi' which is used in Bangladesh as a spice and also conceived to have medicinal property for a wide range of disease including bronchitis, asthma, piles and arthritis [15]. In Bangladesh and India P. chaba is popularly known as 'Choi', mostly used as a spice and used for a variety of disease for a belief to have medicinal activity [15]. Traditionally in different countries it is used as an anti-flatulent, gastro-protective, appetizing property, as an expectorant, antitussive, anti-fungal agent. It also possesses cholesterol lowering properties and as a component of digestive and sleep-inducing preparation [16]. Previously reported that; chloroform extracts, extract of petroleum ether, ethyl acetate and methanolic extracts of $P$. chaba (Choi) roots showed antibacterial and antifungal properties compared with primary standard drugs Kanamycin and Nystatin, respectively and it contains compounds bornyl piperate, piperlonguminine, - 1-undecylenyl3,4-methyllenedioxy benzene, $\alpha$ - amyrin, $\beta$ - sitosterol, Chavicine, Cineol terpinan-4, 1- $\beta$ - caryophyllene, Fructose, Glucose, Guineesine, lignan, N-isobutyl-decatrans-2,trans-4dienanmide, Palmitic acid, Pellitorine, Piperidine, Piperoctadecalidine, Piperine, Piperlonguminirine, Pipernonaline, Pipereicosalidine, Piplartine, Retrofractamide-D, Sesamin, Tetrahydropiperic acid and Veneol etc. [17, 18].

We aimed in this study, to determine the in-vitro antiinflammatory action of $P$. chaba root for ethanolic extract and further confirmation using molecular docking approach.

\section{Material and methods \\ Plant collection and identification}

The root of $P$. chaba about $5 \mathrm{~kg}$ were collected from the district of Bagerhat, Bangladesh, in the month of August 2015. The plant was authenticated by, Bangladesh National Herbarium (BNH) Mirpur, Dhaka, Bangladesh and a voucher specimen has been deposited in Bangladesh National Herbarium, voucher number43198. The fresh roots were collected and preserved in Phytochemistry lab, Department of Pharmacy, University of Rajshahi, Bangladesh.

\section{Preparation of plant material}

After washing the roots were cut into small parts. Parts were dried under the mild sun and finally dried in an oven at $40-45^{\circ} \mathrm{C}$ for $36 \mathrm{~h}$. After complete drying, the dried materials then fine-grained using a grinding machine to form a coarse powder (FFC-15, China) were stacked away for future use conserving in hermetically sealed container.

\section{Extraction with solvent}

Extraction is the process in which the plant materials are treated with specific solvents whereby both medicinally active and inactive constituents are dissolved out. Powdered plant materials (roots) having a weight of about $700 \mathrm{~g}$ were taken in 3 different amber-colored reagent bottles separately and soaked in $700 \mathrm{ml}$ of ethanol (98\% pure) in each bottle. Then the plant extract was sealed for 5 days with episodic stirring. Firstly, filtering through cotton and then using Whatman No.1 filter papers the filtration process was meticulously done. The overall filtering process ran for consecutive three times 
and then the solvent and extract mixture decocted using a rotary evaporator at $45^{\circ} \mathrm{C}$ under reduced vapor pressure to yield crude plant extract.

\section{Anti-inflammatory activity}

The following standard methods were used for in vitro anti-inflammatory evaluation of crude ethanolic extract of $P$. chaba roots.

\section{Human red blood cell (HRBC) membrane stabilization assay}

To examine in vitro anti-inflammatory action of extract HRBC membrane stabilization technique is incorporated by following Gandhidasan et al. [19]. NSAIDs were used as standard and anti-inflammatory activity was expressed as the percentage of RBC lysis. HRBC membrane act similar as the lysosomal membrane [20]. If it stabilizes by using the extract it also stabilizes the lysosomal membrane. Spectrophotometer at $560 \mathrm{~nm}$ range was used for estimation of hemoglobin content in the suspension. Healthy human volunteer donated blood while any consumption of NSAIDs prior 2 weeks of the experiment are considered to be the prime exclusion criteria. NaOxalate was used to prevent clotting. All the blood samples were stored at $4{ }^{\circ} \mathrm{C}$ for $24 \mathrm{~h}$ before use. Centrifugation for 5 mins at $2500 \mathrm{rpm}$ was used for supernatant removal. Sterile saline solution $(0.9 \% \mathrm{w} / \mathrm{v} \mathrm{NaCl})$ was used for washing and centrifugation was done at 2500 rpm for $5 \mathrm{~min}$. The process of clearing supernatant was done in three repeated times and the packed cell volume was measured. For cellular component reconstitution a $40 \%$ suspension (v/v) mixed with phosphate-buffered saline $(10 \mathrm{mM}, \mathrm{pH} 7.4)$ comprised in $1 \mathrm{~L}$ of distilled water, $\mathrm{NaH}_{2} \mathrm{PO}_{4} \cdot 2 \mathrm{H}_{2} \mathrm{O}-0.26$ g; $\mathrm{Na}_{2} \mathrm{HPO}_{4}-1.15 \mathrm{~g} ; \mathrm{NaCl}-9$ g.

\section{Heat-induced hemolysis}

Portion of $5 \mathrm{ml}$ of the isotonic buffer containing $50 \mu \mathrm{g} /$ $\mathrm{ml}, 100 \mu \mathrm{g} / \mathrm{ml}, 200 \mu \mathrm{g} / \mathrm{ml}, 400 \mu \mathrm{g} / \mathrm{ml}$ and $800 \mu \mathrm{g} / \mathrm{ml}$ of an ethanol solution of crude extract was put into two duplicate sets of centrifuge tubes. The same amount of vehicles was added up in another tube as control. $50 \mu \mathrm{l}$ of $\mathrm{RBC}$ suspension was contributed to each tube and mingled gently by inverting the test tube. One pair of tubes were incubated at $54^{\circ} \mathrm{C}$ temperature, $20 \mathrm{~min}$ in water bath. Other pair was preserved at temperature 0$5{ }^{\circ} \mathrm{C}$ in ice bath. Centrifugation of the mixture was done at $540 \mathrm{~nm}$ for $5 \mathrm{~min}$ at $5000 \mathrm{rpm}$ and the absorbance was taken at $560 \mathrm{~nm}$ by using a spectrophotometer. Acetyl salicylic acid (ASA) $200 \mu \mathrm{g} / \mathrm{ml}$ was used as a reference standard. The percent inhibition of hemolysis was calculated according to the equation:

$$
\begin{aligned}
\text { \%inhibition of hemolysis }= & 100 \\
& \times\left(1-\frac{\mathrm{OD}_{2}-\mathrm{OD}_{1}}{\mathrm{OD}_{3}-\mathrm{OD}_{1}}\right)
\end{aligned}
$$

Where, $\quad \mathrm{OD}_{1}=$ Test Sample Unheated; $\mathrm{OD}_{2}=$ Test Sample Heated and $\mathrm{OD}_{3}=$ Control Sample Heated.

\section{Hypotonicity-induced hemolysis}

The isotonic solution was made by composing $154 \mathrm{mM}$ $\mathrm{NaCl}$ in $10 \mathrm{mM}$ sodium phosphste solution and the buffer of this solution was $7.4 \mathrm{p}^{\mathrm{H}}$. Stock RBC suspension $50 \mu \mathrm{l}$ was mixed with $5 \mathrm{ml}$ of the hypotonic solution containing the $P$. chaba ethanolic extract at concentrations of $50,100,200,400$ and $800 \mu \mathrm{g} / \mathrm{ml}$, while the control sample was mixed with drug-free solution. After incubating for $10 \mathrm{~min}$ at room temperature the whole mixture was centrifuged $5000 \mathrm{rpm}$ for $5 \mathrm{~min}$ and at 540 $\mathrm{nm}$, the absorbance of the supernatant was assessed using UV-spectrophotometer. Acetyl salicylic acid (ASA) $200 \mu \mathrm{g} / \mathrm{ml}$ was used as a reference standard. The percent inhibition of hemolysis was calculated according to the equation:

$$
\begin{aligned}
\text { \%inhibition of hemolysis }= & 100 \\
& \times\left(1-\frac{\mathrm{OD}_{2}-\mathrm{OD}_{1}}{\mathrm{OD}_{3}-\mathrm{OD}_{1}}\right)
\end{aligned}
$$

Where, $\mathrm{OD}_{1}=$ Test sample in isotonic solution; $\mathrm{OD}_{2}=$ Test sample hypotonic solution and $\mathrm{OD}_{3}=$ Control sample in hypotonic solution.

\section{Egg albumin denaturation assay}

Inflammatory and arthritic diseases are produced by denaturation of protein and a yield of autoantigen in several arthritic diseases might be for in vivo denaturation of proteins. So agents having the property of protein denaturation can be used for the anti-inflammatory drug development. In percent investigation, the in vivo antiinflammatory effect of $P$. chaba was evaluated against denaturation of egg albumin. The reaction mixture (5 $\mathrm{ml}$ ) consisted of the $0.2 \mathrm{ml}$ of egg albumin with saline of $2.8 \mathrm{ml}$ phosphate buffer (PBS, $\mathrm{pH} 6.4$ ) and $2 \mathrm{ml}$ of changing concentrations of $P$. chaba extract so that terminal concentrations become $200 \mu \mathrm{g} / \mathrm{ml}, 400 \mu \mathrm{g} / \mathrm{ml}, 600 \mu \mathrm{g} / \mathrm{ml}$, $800 \mu \mathrm{g} / \mathrm{ml}$ and $1000 \mu \mathrm{g} / \mathrm{ml}$. The similar volume of distilled water was used as control substance. Incubation was done for $15 \mathrm{~min}$ at $37.2^{\circ} \mathrm{C}$ and after that it was heated for $5 \mathrm{~min}$ at $70^{\circ} \mathrm{C}$. After that absorbance was measured at $660 \mathrm{~nm}$. For reference acetyl salicylic acid (ASA) at the final concentration of $(200,400,600,800$ and $1000 \mu \mathrm{g} / \mathrm{ml}$ ) was used at similar absorbance [21].

Following formula is used for calculating inhibition of protein denaturation: 
\%inhibition of egg albumin denaturation

$$
=100 \times\left(1-\frac{\mathrm{OD}_{2}-\mathrm{OD}_{1}}{\mathrm{OD}_{3}-\mathrm{OD}_{1}}\right)
$$

Where, $\quad \mathrm{OD}_{1}=$ Test Sample Unheated; $\mathrm{OD}_{2}=$ Test sample Heated and $\mathrm{OD}_{3}=$ Control Sample Heated.

\section{Statistical analysis}

The results are expressed as mean \pm SD using Graph Pad Prism (version 7). We used a one-way analysis of variance (ANOVA), followed by Scheffe's post-hoc test or students paired or unpaired t-test where appropriate. The statistical method applied in each analysis was described in each figure. Results were considered to be significant when $p$-values were less than $0.05(p<0.05)$.

\section{In silico molecular docking}

\section{Protein preparation}

3-D crystal structure of the, catalytic domain of Cyclooxygenase-1 (PDB ID: 2OYE), Cyclooxygenase-2 (PDB ID: 6COX) and NF-kB (nuclear factor kappa light chain enhancer) (PDB ID: 5LDE) were downloaded using the Protein Data Bank database [22]. Following that, utilizing Protein Preparation Wizard of Schrödinger- Maestro v10.1 the protein structures were prepared and rectified. After that using Force Field OPLS_2005, setting maximum heavy atom RMSD (root mean square deviation) at $0.30 \AA$; downplay of energy was carried out.

\section{Ligand preparation}

Employing PubChem database, six major representative compound structures i.e., bornyl piperate (CID: 274465980), piperine (CID: 638024) and piperlonguminine (CID: 5320621) were regained. Then ligands to be docked were prepared with Lig-Prep tool ingrained in
Maestro 2015, followed by neutralization at $\mathrm{pH} 7.0 \pm 2.0$ using Epik and understated by force field OPLS-2005.

\section{Receptor grid generation}

For Glide ligand docking; receptor grids were calculated for the prepared receptors for searching suitable docking sites so that several ligands attach within the portended active site while molecular docking. In Glide, by maintaining the default parameters of Van der Waals scaling factor at 1.00 including charge cutoff at 0.25 subjugated to force field OPLS-2005 grids were generated. A cubiclike box of defined dimensions centered of the active site residues at the centroid (Reference ligand active site) was automatically generated for the receptor protein. Bounding box with a dimension of $14 \AA \times 14 \AA \times 14 \AA$ was set for docking experiments.

\section{Glide standard precision (SP) ligand docking}

Using, Glide of Schrödinger-Maestro v 10.1 standard precision flexible ligand docking with receptor was carried out, where sanctions were applied for any non-cis/ trans amide bonds. The scaling factor for Van der Waals and partial charge cutoff for ligand atoms were choose to be 0.80 and 0.15 respectively. Final scoring was performed on energy-minimized poses and displayed as Glide score. For each ligand, the best- docked pose (Figs. 1,2 and 3) with lowest Glide score value was recorded $[23,24]$.

\section{Results}

Effect of CEE (crude ethanolic extract) and ASA (acetyl salisylic acid) on heat-induced hemolysis of RBC membrane

The recorded value of effect of CEE of Piper chaba roots and ASA on heat-induced hemolysis of RBC membrane is given in Table 1.

Table 1 Effect of CEE and ASA on heat-induced hemolysis of RBC membrane

\begin{tabular}{|c|c|c|c|c|c|c|c|c|}
\hline \multirow[t]{2}{*}{ Sample } & \multirow{2}{*}{$\begin{array}{l}\text { Conc. } \\
(\mu \mathrm{g} / \\
\mathrm{ml})\end{array}$} & \multicolumn{3}{|c|}{ Absorbance } & \multicolumn{3}{|c|}{$\%$ of inhibition of RBC haemolysis } & \multirow{2}{*}{$\begin{array}{l}\% \text { Inhibition } \\
\text { (Mean } \pm \text { SD) }\end{array}$} \\
\hline & & a & $b$ & $c$ & a & $b$ & C & \\
\hline \multirow[t]{5}{*}{ ASA } & 100 & 0.267 & 0.265 & 0.26 & 13 & 14 & 18 & $15 \pm 2.646$ \\
\hline & 200 & 0.255 & 0.254 & 0.254 & 26 & 25 & 25 & $25.333 \pm 0.577$ \\
\hline & 300 & 0.234 & 0.233 & 0.234 & 41 & 61 & 41 & $47.667 \pm 11.547$ \\
\hline & 400 & 0.234 & 0.233 & 0.233 & 68 & 71 & 69 & $69.333 \pm 1.528$ \\
\hline & 500 & 0.23 & 0.233 & 0.23 & 79 & 76 & 79 & $78 \pm 1.7320$ \\
\hline \multirow[t]{5}{*}{ CEE } & 100 & 0.269 & 0.25 & 0.245 & 23 & 47 & 53 & $41 \pm 15.875$ \\
\hline & 200 & 0.243 & 0.24 & 0.24 & 49 & 50 & 50 & $49.667 \pm 0.577$ \\
\hline & 300 & 0.235 & 0.233 & 0.23 & 56 & 55 & 58 & $56.333 \pm 1.527$ \\
\hline & 400 & 0.233 & 0.235 & 0.233 & 65 & 62 & 69 & $65.333 \pm 3.512$ \\
\hline & 500 & 0.225 & 0.233 & 0.23 & 32 & 61 & 65 & $52.667 \pm 18.009$ \\
\hline
\end{tabular}




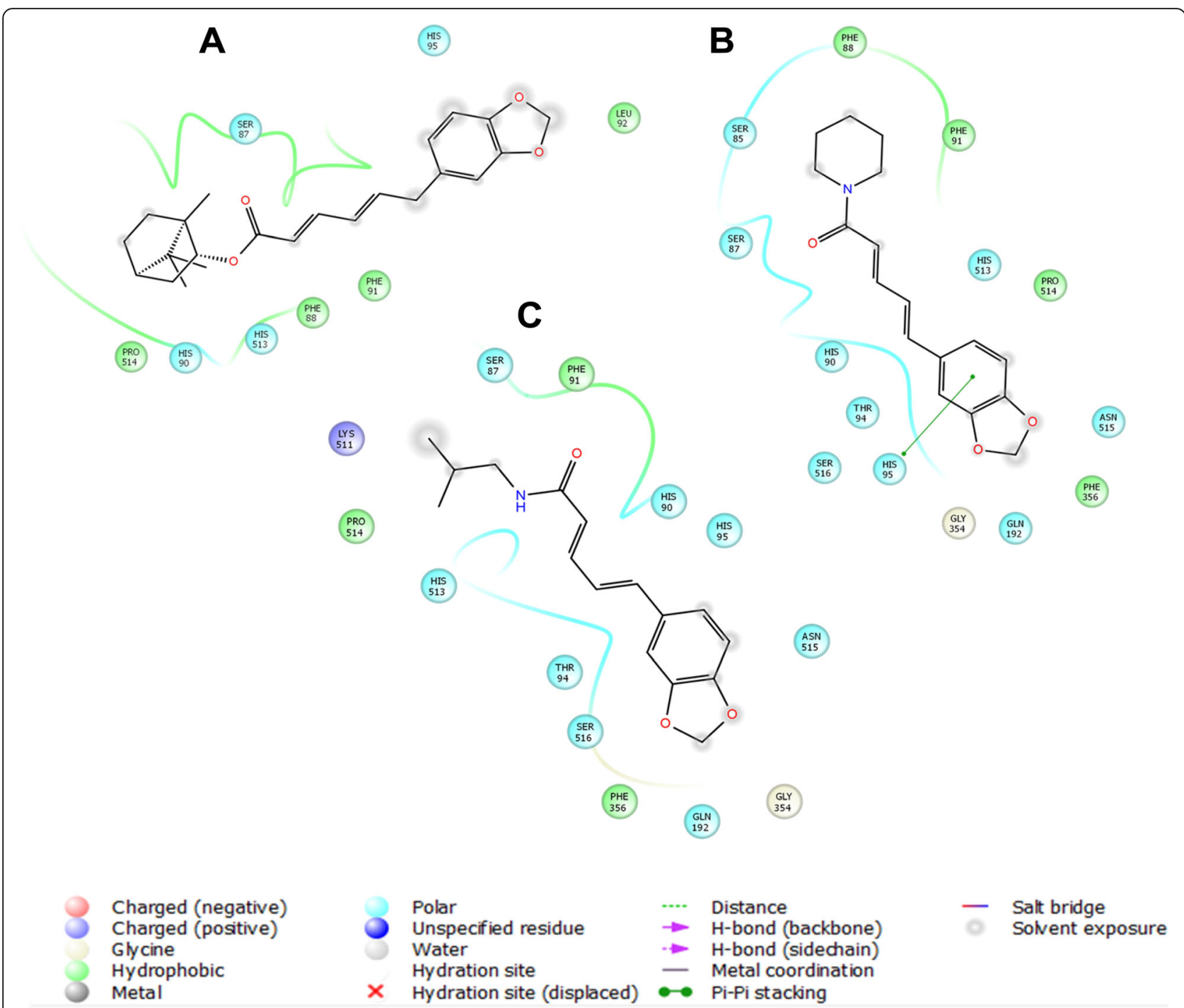

Fig. 1 Docking result of a (bornyl piperate), b (piperine) and $\mathbf{c}$ (piperlonguminine) with COX-1 (PDB: 2OYE)

Effect of CEE (crude ethanolic extract) and ASA (acetyl salisylic acid) on hypotonicity-induced hemolysis of RBC membrane

The recorded value of effect of CEE of Piper chaba roots and ASA on hypotonicity-induced hemolysis of RBC membrane is given in Table 2 .

\section{Evaluation of anti-inflammatory activity by egg albumin denaturation}

In case of inflammatory arthritic diseases modification of tissue proteins occurs which is well-documented in several previous studies. In vivo denaturation of proteins and synthesis of auto antigen could be a hallmark marker of arthritic disease. Test results are shown in Table 3.
In silico study: molecular docking for anti-inflammatory activity

In this study among the three compounds which were isolated from Piper chaba root were performed molecular docking against Cyclooxygenase enzyme 1 (COX 1) (PDB ID: 2OYE) (Fig. 1), Cyclooxygenase enzyme 2 (COX 2) (PDB ID: 6COX) (Fig. 2) and NF-kB (nuclear factor kappa light chain enhancer) (PDB ID: 5LDE) (Fig. 3). From Tables 4 and 6 , piperine showed best docking score against COX 1 and NF-kB. On the other hand, in Table 5, piperlonguminine showed best docking score against COX 2 .

\section{Discussion}

The study involved using anti-inflammatory extracts as an important aspect. There are so many extracts or compounds which might show anti-inflammatory effects. 
Table 2 Effect of CEE and ASA on hypo tonicity induced hemolysis of RBC membrane

\begin{tabular}{|c|c|c|c|c|c|c|c|c|}
\hline \multirow[t]{2}{*}{ Sample } & \multirow{2}{*}{$\begin{array}{l}\text { Conc. } \\
(\mu \mathrm{g} / \\
\mathrm{ml})\end{array}$} & \multicolumn{3}{|c|}{ Absorbance } & \multicolumn{3}{|c|}{$\%$ of inhibition of RBC haemolysis } & \multirow{2}{*}{$\begin{array}{c}\text { \% Inhibition } \\
(\text { Mean } \pm \text { SD) }\end{array}$} \\
\hline & & a & $b$ & c & a & $b$ & c & \\
\hline \multirow[t]{5}{*}{ ASA } & 100 & 0.838 & 0.83 & 0.835 & 13 & 14 & 13 & $13.333 \pm 0.577$ \\
\hline & 200 & 0.75 & 0.75 & 0.74 & 23 & 23 & 24 & $23.333 \pm 0.577$ \\
\hline & 300 & 0.626 & 0.62 & 0.63 & 38 & 37.5 & 37 & $37.5 \pm 0.5$ \\
\hline & 400 & 0.6 & 0.61 & 0.6 & 40 & 39 & 40 & $39.667 \pm 0.577$ \\
\hline & 500 & 0.425 & 0.42 & 0.43 & 59 & 60 & 58 & $59 \pm 1$ \\
\hline \multirow[t]{5}{*}{ CEE } & 100 & 0.842 & 0.84 & 0.844 & 13 & 13 & 12 & $12.667 \pm 0.577$ \\
\hline & 200 & 0.711 & 0.71 & 0.715 & 28 & 28 & 27 & $27.667 \pm 0.577$ \\
\hline & 300 & 0.7 & 0.71 & 0.7 & 28 & 27 & 28 & $27.667 \pm 0.577$ \\
\hline & 400 & 0.68 & 0.68 & 0.675 & 30 & 30 & 31 & $30.333 \pm 0.577$ \\
\hline & 500 & 0.65 & 0.65 & 0.6 & 34 & 34 & 39 & $35.667 \pm 2.887$ \\
\hline
\end{tabular}

This effect can be demonstrated by heat-induced membrane stabilization method, hypotonicity induced HRBC membrane stabilization method and egg albumin antidenaturation method. It is a concentration-dependent process and protection increased with increase in the concentration of the sample.

Recent study with $P$. chaba and $P$. interruptum ethanolic extract inhibited ear edema that was induced by ethyl phenylpiolate and edema of hind paws in carrageenan induced rat models [25]. Though having some concern about procedure of the conducted study and for suspicious bias detection reports of those studies showed great promise for future study.

One of the major and well documented cause of inflammation is denaturation of proteins. The investigation is done on the mechanism of anti-inflammation activity. The further study was done on the ability of the extract to inhibit protein denaturation as the part of the investigation. For denaturation of albumin protein it seemed very efficient. The active compounds obtained from the plant part

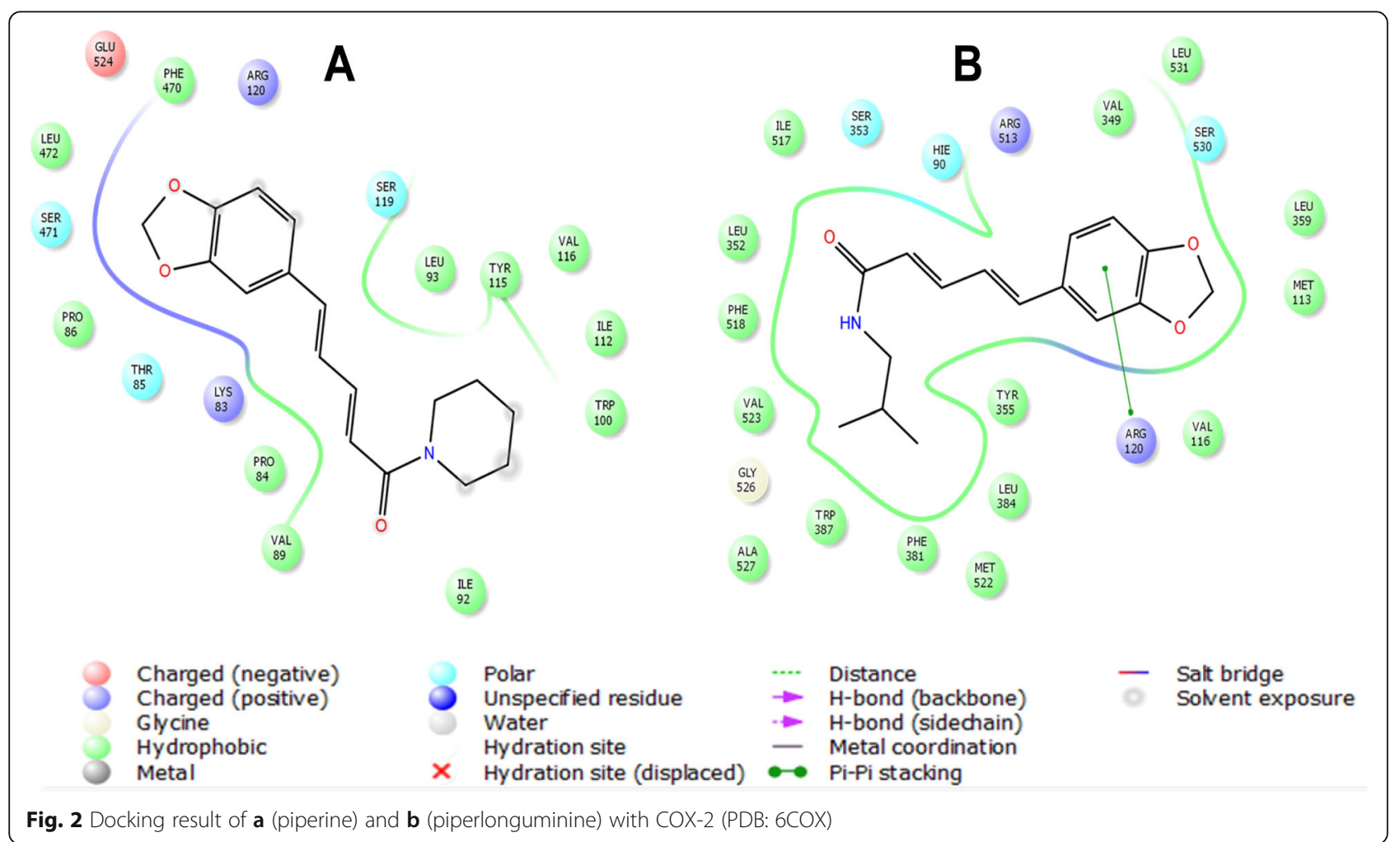


Table 3 Effect of CEE and ASA on egg albumin denaturation

\begin{tabular}{|c|c|c|c|c|c|c|c|c|}
\hline \multirow[t]{2}{*}{ Sample } & \multirow{2}{*}{$\begin{array}{l}\text { Conc. } \\
(\mu \mathrm{g} / \\
\mathrm{ml})\end{array}$} & \multicolumn{3}{|c|}{ Absorbance } & \multicolumn{3}{|c|}{$\%$ of inhibition of egg albumin denaturation } & \multirow{2}{*}{$\begin{array}{c}\% \text { Inhibition } \\
(\text { Mean } \pm \text { SD) }\end{array}$} \\
\hline & & a & $\mathrm{b}$ & c & a & $b$ & c & \\
\hline \multirow[t]{5}{*}{ CEE } & 200 & 1.257 & 1.255 & 1.255 & 3 & 4 & 4 & $3.667 \pm 0.577$ \\
\hline & 400 & 1.097 & 1.099 & 1.09 & 24 & 20 & 20 & $21.333 \pm 2.309$ \\
\hline & 600 & 1.033 & 1.03 & 1.033 & 24 & 24 & 24 & $24 \pm 0$ \\
\hline & 800 & 0.701 & 0.703 & 0.701 & 51 & 52 & 52 & $51.667 \pm 0.577$ \\
\hline & 1000 & 0.513 & 0.515 & 0.513 & 64 & 64 & 52 & $60 \pm 6.9282$ \\
\hline \multirow[t]{5}{*}{ ASA } & 200 & 0.319 & 0.32 & 0.32 & 77.44 & 77.36 & 77.43 & $77.41 \pm 0.043$ \\
\hline & 400 & 0.277 & 0.277 & 0.275 & 80.48 & 80.48 & 80.7 & $80.553 \pm 0.127$ \\
\hline & 600 & 0.198 & 0.195 & 0.198 & 86.6 & 86.7 & 86.6 & $86.633 \pm 0.057$ \\
\hline & 800 & 0.086 & 0.088 & 0.086 & 95.3 & 97.3 & 95.39 & $95.997 \pm 1.129$ \\
\hline & 1000 & 0.061 & 0.061 & 0.063 & 97 & 97.22 & 97.14 & $97.12 \pm 0.111$ \\
\hline
\end{tabular}

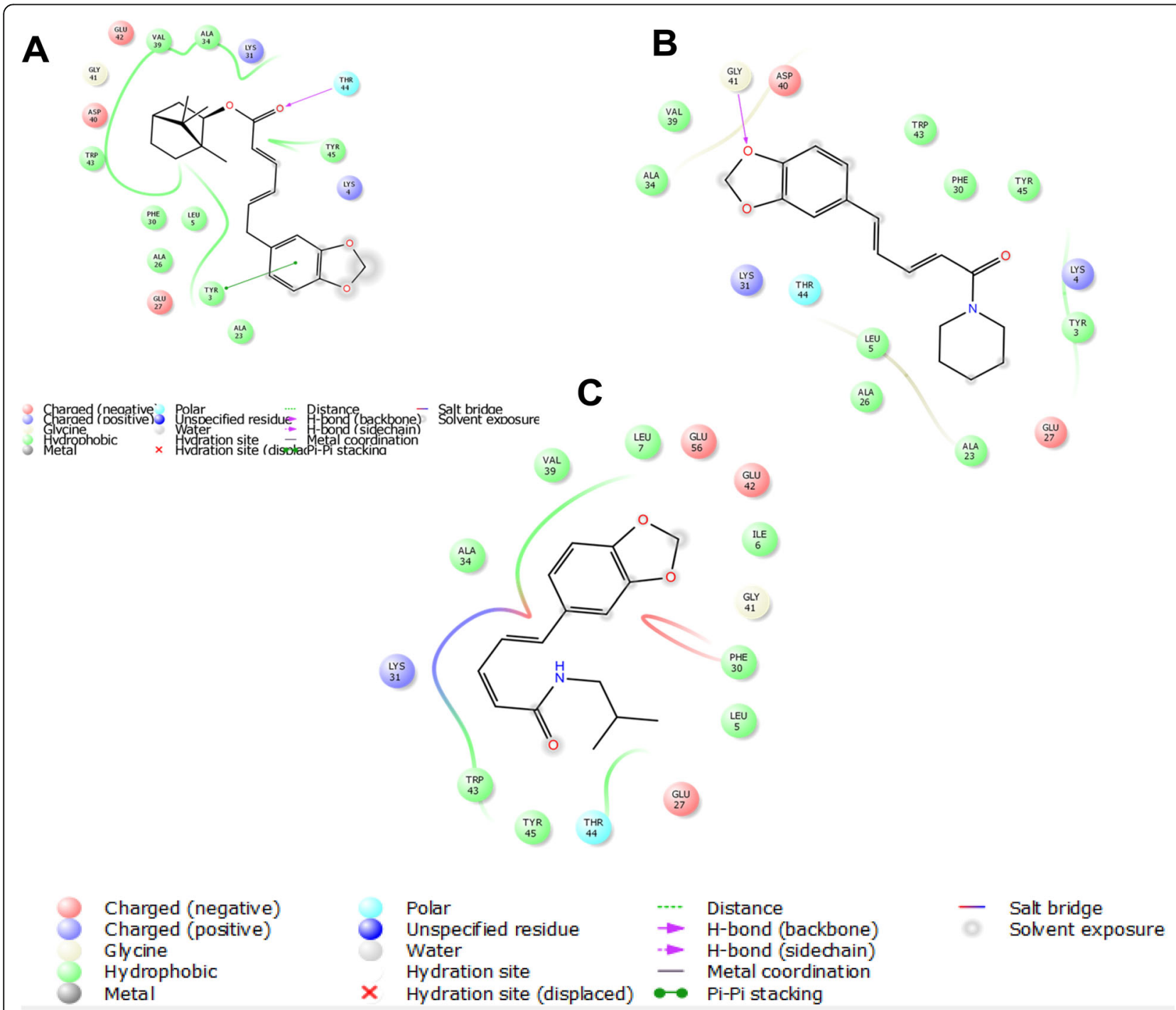

Fig. 3 Docking result of a (bornyl piperate), b (piperine) and c (piperlonguminine) with NF-KB (PDB: 5LDE) 
Table 4 Docking result of bornyl piperate, piperine and piperlonguminine with COX-1 (PDB: 2OYE)

\begin{tabular}{lll}
\hline Compound Name & Compound ID & Docking Score \\
\hline bornyl piperate & $274,465,980$ & -2.909 \\
piperine & 638,024 & -5.648 \\
piperlonguminine & $5,320,621$ & -4.956
\end{tabular}

also had more or less anti-inflammatory activity. Acetyl salicylic acid a standard anti-inflammatory drug showed the maximum inhibition of $78 \%$ at the concentration of $500 \mu \mathrm{g} / \mathrm{ml}$, whereas CEE of $P$. chaba showed $52.6 \%$ at that concentration. The extracts were effectively inhibiting the heat-induced hemolysis. An evidence regarding membrane stabilization is obtained from these results. The evidence proves that membrane stabilization is an additional mechanism of anti-inflammatory effect of the extract. Release of lysosomal contents from neutrophils might be inhibited at the inflammation sites for membrane stabilization [26].

The hypotonic solution has hemolytic effect. Hemolysis occurs when there is accumulation of excessive fluid into the cells resulting in rupture of the $\mathrm{RBC}$ membrane. When the red cell membrane gets injured, it will make the cell more susceptible to secondary damage. This damage is occurred by free radical-induced lipid peroxidation [27] The leakage of serum protein and fluids into the tissue can be prevented by membrane stabilization. This process go on by inflammatory intermediators where there is an increase in permeability of membrane [28]. Ethanolic root-extract of $P$. chaba extract might be stabilize the membrane of RBC by precluding the discharge of lytic enzymes and other active inflammatory mediators. At lower dose $100 \mu \mathrm{g} / \mathrm{ml}$ the CEE of P. chaba showed almost similar activity compared to a reference standard.

For the evaluation of anti-inflammatory property of $P$ chaba, the anti-denaturation method of egg albumin was chosen. In the assay of anti-denaturation method, the egg albumin is denatured. This denaturation is induced by heat treatment. Some antigens are expressed by denatured proteins. These antigens are associated with hypersensitive reactions (type-III) which are associated with some diseases for example glomerulonephritis and serum sickness [29]. Heat denatured proteins can provoke delayed hypersensitivity. These proteins are as

Table 5 Docking result of bornyl piperate, piperine and piperlonguminine with COX-2 (PDB: 6COX)

\begin{tabular}{llc}
\hline Compound Name & Compound ID & Docking Score \\
\hline bornyl piperate & $274,465,980$ & \\
piperine & 638,024 & -4.285 \\
piperlonguminine & $5,320,621$ & -4.392 \\
\hline
\end{tabular}

effective as native proteins in such provoking [30]. Moreover, it has already been proved that conventional NSAID's like phenylbutazone and indomethacin don't only inhibit the endogenous prostaglandins production by blocking COX enzyme. In addition, they also prevent denaturation of proteins [31]. That's why for checking the anti-inflammatory activity, anti-denaturation assay is the convenient method. It can be observed from the present study that the extract has shown considerable anti-inflammatory activity. $P$. chaba is capable of controlling the production of autoantigen. Thus, it can inhibit the denaturation of proteins. This effect was compared with a standard drug. Aspirin was taken as standard drug for the comparison. In preliminary phytochemical screening, the secondary metabolites like phenolic compounds and alkaloids were found. These compounds might be responsible for such activity.

Nowadays molecular docking studies have been widely used to predict the ligand-target prediction and to obtain the biological activity of the natural products. Again, it gives us not only the possible mechanism of action of a protein or enzyme but also the binding moods inside the binding site of proteins or enzyme. So, we have also used the molecular docking of some compounds of $P$. chaba to make a collaboration between this compounds and different types of enzymes responsible for inflammation to illustrate the biochemical process of the antiinflammatory activity [32-34]. These compounds were docked against three targets which were COX-1 (PDB ID: 2OYE), COX-2 (PDB ID: 6COX) and NF- $\mathrm{k} \beta$ (PDB ID: $5 \mathrm{LDE}$ ). From Tables 4 and 6 , we can see that piperine give the best docking score against COX-1 and NF$\kappa \beta$ followed by bornyl piperate and piperlonguminine. It has been previously reported piperine have both analgesic and anticonvulsant effect [27]. But on the other hand, piperlonguminine showed highest docking score against COX-2 among of these three compounds in Table 5, which has been previously reported $[35,36]$. In summary, the comprehensive analysis by using the complementary tool support the traditional use of this plant.

\section{Conclusions}

The investigation indicated that the ethanolic root extract of $P$. chaba shows significant inhibition of hemolysis in vitro. Also, the inhibition effect confirmed
Table 6 Docking result of bornyl piperate, piperine and piperlonguminine with NF-kB (PDB: 5LDE)

\begin{tabular}{lll}
\hline Compound Name & Compound ID & Docking Score \\
\hline bornyl piperate & $274,465,980$ & -4.33 \\
piperine & 638,024 & -5.891 \\
piperlonguminine & $5,320,621$ & -4.733 \\
\hline
\end{tabular}


by crude extracts of $P$. chaba was promising with that of standard drug acetylsalicylic acid. Moreover, from the in silico PASS prediction, the isolated phytoconstituents are significantly impacted in in vitro activities. This experimental evidence indicates $P$. chaba root extracts could have potential therapeutic efficacy in disease processes causing destabilization of biological membranes. The result of the present study assumed that this plant could play a dynamic role in anti-inflammatory activity.

\section{Acknowledgements}

The authors gratefully acknowledge Department of Pharmacy, University of Rajshahi, Bangladesh for providing financial support to conduct this research work.

\section{Declarations}

All authors read the manuscript and approved it for submission. No portion or part of the manuscript has been published earlier, nor is any part of it under consideration for publication at another journal.

\section{Authors' contributions}

This work was carried out in coaction among all authors. All the authors have accepted responsibility for the whole content of this manuscript and approved for submission. Authors S.Y.; A. B. M. A. R and S. F. A collected the plant and prepared the extracts and fractions. S.Y.; A. B. M. A. R and S. F. A carried out the study design, performed the experiments, data collection, data interpretation, manuscript preparation, statistical analysis. Author A.P. performed the in silico docking study. S. Y. and S. A. S prepared the manuscript draft. T. N., M. I. I. W. and T. B. E designed and planned the studies, supervised the experiments and revised the manuscript for necessary changes in format, grammar and English standard and has thoroughly checked all authors read and approved the final version of the manuscript. All authors read and approved the final manuscript.

\section{Funding}

This work is managed to perform with the individual funding of all authors.

\section{Availability of data and materials}

Not applicable.

\section{Ethics approval and consent to participate}

Not applicable.

\section{Consent for publication}

Not applicable.

\section{Competing interests}

The authors declare that they have no competing interests.

\section{Author details}

'Department of Pharmacy, University of Rajshahi, Rajshahi 6205, Bangladesh. ${ }^{2}$ Department of Pharmacy, Atish Dipankar University of Science \& Technology, Dhaka 1230, Bangladesh. ${ }^{3}$ Department of Pharmacy, BGC Trust University Bangladesh, Chittagong 4381, Bangladesh. ${ }^{4}$ Drug Discovery, GUSTO A Research Group, Chittagong 4000, Bangladesh. ${ }^{5}$ Department of Pharmacy, Noakhali Science and Technology University, Noakhali 3814, Bangladesh. ${ }^{6}$ Pratyasha Health Biomedical Research Center, Dhaka 1230, Bangladesh.

Received: 29 November 2019 Accepted: 21 August 2020

Published online: 27 August 2020

\section{References}

1. De Pasquale A. Pharmacognosy: the oldest modern science. J Ethnopharmacol. 1984;11:1-16 Elsevier.

2. Ji H, Li X, Zhang H. Natural products and drug discovery. EMBO Rep. 2009; 10:194-200 John Wiley \& Sons, Ltd.

3. Parker G. The military revolution: military innovation and the rise of the west, 1500-1800. Cambridge: Cambridge University Press; 1996.
4. Sandoval M, Okuhama NN, Zhang X-J, Condezo LA, Lao J, Angeles FM, et al. Anti-inflammatory and antioxidant activities of cat's claw (Uncaria tomentosa and Uncaria guianensis) are independent of their alkaloid content. Phytomedicine. 2002;9:325-37 Elsevier.

5. Ferrero-Miliani L, Nielsen OH, Andersen PS, Girardin SE. Chronic inflammation: importance of NOD2 and NALP3 in interleukin-1 $\beta$ generation. Clin Exp Immunol. 2007;147:227-35 Wiley Online Library.

6. Hadjigogos $K$. The role of free radicals in the pathogenesis of rheumatoid arthritis. Panminerva medica. 2003;45(1):7.

7. Emran $\mathrm{TB}$, Uddin MMN, Rahman MA, Hossain MI, Islam MM, Kabir MI. In vitro erythrocyte membrane stabilization properties of Solanum aethiopicum L. Fruit Extracts. Biores Comm. 2015;1:111-5.

8. Ravikiran G, Elumalai A, Eswaraiah MC, Naresh V. An annual review on antiinflammatory medicinal plants. Int J Phytomed. 2011;5:198-206.

9. Reynolds JF, Noakes TD, Schwellnus MP, Windt A, Bowerbank P. Nonsteroidal anti-inflammatory drugs fail to enhance healing of acute hamstring injuries treated with physiotherapy. S Afr Med J. 1995;85(6):51722.

10. Terry R, Posadzki P, Watson LK, Ernst E. The use of ginger (Zingiber officinale) for the treatment of pain: a systematic review of clinical trials. Pain Med. 2011:12:1808-18 Blackwell Publishing Inc Malden, USA.

11. Mueller M, Hobiger S, Jungbauer A. Anti-inflammatory activity of extracts from fruits, herbs and spices. Food Chem. 2010;122:987-96 Elsevier.

12. Alam B, Akter F, Parvin N, Pia RS, Akter S, Chowdhury J, et al. Antioxidant, analgesic and anti-inflammatory activities of the methanolic extract of Piper betle leaves. Avicenna J Phytomed. 2013;3:112 Mashhad University of Medical Sciences.

13. Pachpute AP, Deshmukh TA. Antioxidant and Hepatoprotective activity of an ethanol extract of Piper Cubeba fruits. Int J Res Dev Pharm L Sci. 2013;2: 321-9.

14. Ahmad F, Sirat HM, Jamaludin F, Mustapha NM, Ali RM, Arbain D, et al. Antimicrobial and anti-inflammatory activities of Piper porphyrophyllum (Fam. Piperaceae). Arab J Chem. 2014;7:1031-3 Elsevier.

15. Begum F, Uddin K, Sultana S, Ferdous AH, Begum ZA. Effects of methanol extract of Piper chaba stem bark on chronic Inflamation in rats. Ibrahim Med Coll J. 2008:2:37-9.

16. JunShik C, Xiuguo $L$. The Effect of Quercetin on the Pharmacokinetics of Verapamil in Rabbits. 2004:4:347.

17. Martha Perez Gutierrez R, Maria Neira Gonzalez A, Hoyo-Vadillo C. Alkaloids from piper: a review of its phytochemistry and pharmacology. Mini-Rev Med Chem. 2013;13:163-93 Bentham Science Publishers.

18. Naz T, Mosaddik A, Haque ME. Antimicrobial and cytotoxic activities of root extracts of Piper Chaba. J Sci Res. 2009;1:138-44.

19. Gandhidasan R, Thamaraichelvan A, Baburaj S. Anti inflammatory action of Lannea coromandelica by HRBC membrane stabilization. Fitoterapia. 1991; 62:81-3.

20. Chou C. The Antiinflammatory effect of an extract of Tripterygium wilfordii hook F on adjuvant-induced paw Oedema in rats and Inflammatory mediators release. Phyther Res An Int J Devoted to Med Sci Res Plants Plant Prod. 1997;11:152-4 Wiley Online Library.

21. Mehta JP, Parmar PH, Vadia SH, Patel MK, Tripathi CB. In-vitro antioxidant and in-vivo anti-inflammatory activities of aerial parts of Cassia species. Arab J Chem. 2017:10:S1654-62 Elsevier.

22. Berman HM, Westbrook J, Feng Z, Gilliland G, Bhat TN, Weissig H, et al. The protein data bank. Nucleic Acids Res. 2000;28:235-42 View Artic PubMed/ NCBI Google Sch.

23. Halgren TA, Murphy RB, Friesner RA, Beard HS, Frye LL, Pollard WT, et al. Glide: a new approach for rapid, accurate docking and scoring. 2. Enrichment factors in database screening. J Med Chem. 2004;47:1750-9 ACS Publications.

24. Friesner RA, Banks JL, Murphy RB, Halgren TA, Klicic JJ, Mainz DT, et al. Glide: a new approach for rapid, accurate docking and scoring. 1. Method and assessment of docking accuracy. J Med Chem. 2004;47:1739-49 ACS Publications.

25. Sireeratawong $S$, Itharat $A$, Lerdvuthisopon $N$, Piyabhan $P$, Khonsung $P$, Boonraeng S, et al. Anti-Inflammatory, Analgesic, and Antipyretic Activities of the Ethanol Extract of Piper interruptum Opiz. and Piper chaba Linn. ISRN Pharmacol. 2012;2012:480265. https://doi.org/10.5402/2012/480265.

26. Nagababu E, Lakshmaiah N. Inhibition of microsomal lipid peroxidation and monooxygenase activities by eugenol. Free Radic Res. 1994;20:253-66 Taylor \& Francis. 
27. Bukhari IA, Alhumayyd MS, Mahesar AL, Gilani AH. The analgesic and anticonvulsant effects of piperine in mice. J Physiol Pharmacol. 2013:64:789.

28. Chaitanya R, Sandhya S, David B, Vinod KR, Murali S. HRBC membrane stabilizing property of roor, stem and leaf of glochidion velutinum. Int J Res Pharmaceut Biomed Sci. 2011;2:256-9.

29. Ahmad F, Khan RA, Rasheed S. Study of analgesic and anti-inflammatory activity from plant extracts of Lactuca scariola and Artemisia absinthium. J Islam Acad Sci. 1992;5:111-4.

30. Gell PGH. Benacerraf B. - II.: Studies on Hypersensitivity Delayed Hypersensitivity to Denatured Proteins in Guinea Pigs. Immunology. 1959;2: 64 Wiley-Blackwell.

31. Insel PA. Analgesic-antipyretics and antiinflammatory agents. In: Goodman Gilman's Pharmacol basis Ther. 8th ed. New York: Pergamon; 1990. p. 665-6.

32. Paul A, Adnan M, Majumder M, Kar N, Meem M, Rahman MS, et al. Anthelmintic activity of Piper sylvaticum Roxb.(family: Piperaceae): In vitro and in silico studies. Clin Phytoscience. 2018;4:17 SpringerOpen.

33. Khan S, Nazir M, Raiz N, Saleem M, Zengin G, Fazal G, et al. Phytochemical profiling, in vitro biological properties and in silico studies on Caragana ambigua stocks (Fabaceae): a comprehensive approach. Ind Crop Prod. 2019;131:117-24 Elsevier.

34. Adnan M, Chy NU, Mostafa Kamal ATM, Azad MOK, Paul A, Uddin SB, et al, Investigation of the Biological Activities and Characterization of Bioactive Constituents of Ophiorrhiza rugosa var. prostrata (D. Don) \& Mondal Leaves through In Vivo, In Vitro, and In Silico Approaches. Molecules. 2019:24:1367 Multidisciplinary Digital Publishing Institute.

35. Vedhanayaki G, Shastri GV, Kuruvilla A. Analgesic activity of Piper longum Linn. root. India: NISCAIR-CSIR; 2003

36. Chy MNU, Chakrabarty N, Roy A, Paul A, Emu KA, Dutta T, et al. Antibacterial, anthelmintic, and analgesic activities of Piper sylvaticum (Roxb.) leaves and in silico molecular docking and PASS prediction studies of its isolated compounds. J Complement Integr Med. 2019;16:1-13.

\section{Publisher's Note}

Springer Nature remains neutral with regard to jurisdictional claims in published maps and institutional affiliations.

\section{Submit your manuscript to a SpringerOpen ${ }^{\circ}$ journal and benefit from:}

- Convenient online submission

- Rigorous peer review

- Open access: articles freely available online

High visibility within the field

- Retaining the copyright to your article

Submit your next manuscript at $\boldsymbol{\nabla}$ springeropen.com 